\title{
Phosphatidylserine Exposure in Human Red Blood Cells Depending on Cell Age
}

\author{
Mauro C. Wesseling ${ }^{a}$ Lisa Wagner-Britz ${ }^{a}$ Henri Hupperta Benjamin Hanfa \\ Laura Hertz $^{\mathrm{a}}$ Duc Bach Nguyen ${ }^{\mathrm{b}}$ Ingolf Bernhardta
}

aLaboratory of Biophysics, Faculty of Natural and Technical Sciences III, Saarland University, Campus, Saarbrücken, Germany; ${ }^{b}$ Department of Molecular Biology, Faculty of Biotechnology, Vietnam National University of Agriculture, Ngo Xuan Quang, Gia Lam, Hanoi, Vietnam

\section{Key Words}

Red blood cells - Red blood cell age $\mathrm{Ca}^{2+}$ content - Phosphatidylserine exposure • Lysophosphatidic acid - Phorbol-12 myristate-13 acetate - Flow cytometry - Fluorescence imaging

\begin{abstract}
Background/Aims: The exposure of phosphatidylserine (PS) on the outer membrane leaflet of red blood cells (RBCs) serves as a signal for suicidal erythrocyte death or eryptosis, which may be of importance for cell clearance from blood circulation. PS externalisation is realised by the scramblase activated by an increase of intracellular $\mathrm{Ca}^{2+}$ content. It has been described in literature that RBCs show an increased intracellular $\mathrm{Ca}^{2+}$ content as well as PS exposure when becoming aged up to 120 days (which is their life span). However, these investigations were carried out after incubation of the RBCs for $48 \mathrm{~h}$. The aim of this study was to investigate this effect after short-time incubation using a variety of stimulating substances for $\mathrm{Ca}^{2+}$ uptake and PS exposure. Methods: We separated RBCs by age in five different fractions by centrifugation using Percoll density gradient. The intracellular $\mathrm{Ca}^{2+}$ content and the PS exposure of RBCs with different age has been investigated after treatment with lysophosphatidic acid (LPA) as well as after activation of protein kinase C (PKC) using phorbol-12 myristate-13 acetate (PMA). For positive control RBCs were treated with 4-bromo-A23187. Measurement techniques included flow cytometry and live cell imaging (fluorescence microscopy). Results: The percentage of RBCs showing increased $\mathrm{Ca}^{2+}$ content as well as the PS exposure did not change significantly in dependence on cell age after short-time incubation in control experiments (without stimulating substances) or using LPA or PMA. However, we confirm findings reported that $\mathrm{Ca}^{2+}$ content and the PS exposure of RBCs increased after $48 \mathrm{~h}$ incubation. Conclusion: No significant differences of intracellular $\mathrm{Ca}^{2+}$ content and PS exposure can be seen for RBCs of different age in resting state or after stimulation of $\mathrm{Ca}^{2+}$ uptake at short-time incubation.
\end{abstract}




\section{Cellular Physiology Cell Physiol Biochem 2016;38:1376-1390 \\ and Biochemistry Published online: March 24, $2016 \quad \begin{aligned} & \text { DOI: 10.1159/000443081 } 2016 \text { The Author(s). Published by S. Karger AG, Basel } \\ & \text { www.karger.com/cpb }\end{aligned}$ \\ Wesseling et al.: Phosphatidylserine Exposure Depending on Cell Age}

\section{Introduction}

In a population of human red blood cells (RBCs) one can find cells with different age. They have a life span of about 120 days. Depending on age, their density is different. Young cells have a lower density in comparison to old cells [1]. This makes it possible to separate them into fractions with different ages by density gradient centrifugation using Percoll [2, 3]. Which factors are crucial for the aging process and the mechanisms for the removal of damaged or old RBCs from the blood stream is not yet fully understood. It has been described that older RBCs have a higher intracellular $\mathrm{Ca}^{2+}$ content $[4,5]$ leading to an activation of the scramblase, which in turn results in a significant exposure of phosphatidylserine (PS) in the outer membrane leaflet [6-8]. However, the data of Romero and Romero [4] are in our opinion not completely reliable since they are based on fluorescence measurements using fura-2. It has been demonstrated that the fluorescence dye fura- 2 is not applicable for $\mathrm{Ca}^{2+}$ content determinations in RBCs because of the absorption spectrum of haemoglobin ([9], see also [10]). Recently, Makhro et al. [11] reported that reticulocytes obtained from rat blood have a higher $\mathrm{Ca}^{2+}$ content than mature rat RBCs. Unfortunately the $\mathrm{Ca}^{2+}$ content has not been measured directly in these experiments. However, de Haro et al. [10] also found an enhanced intracellular $\mathrm{Ca}^{2+}$ concentration in human reticulocytes compared with mature RBCs. Furthermore, other authors have shown recently that PS exposure of human RBCs is independent of cell age [12]. Only after long-time incubation for $48 \mathrm{~h}$ in Ringer solution a significant increase in the intracellular $\mathrm{Ca}^{2+}$ content as well as PS exposure with cell age could be detected [13].

In previous papers we have shown several mechanisms leading to an enhanced intracellular $\mathrm{Ca}^{2+}$ content of RBCs. One possibility is the opening of the non-specific, voltagedependent cation (NSVDC) channel by lysophosphatidic acid (LPA) or prostaglandin $\mathrm{E}_{2}\left(\mathrm{PGE}_{2}\right)$ $[14,15]$. LPA and $\mathrm{PGE}_{2}$ are local mediators released from platelets after their activation within the coagulation cascade. $\mathrm{PGE}_{2}$ can be released also by RBCs under mechanical stress [16]. We were able to show that PS exposure induced by LPA lead to cell-cell adhesion of human RBCs $[17,18]$. In addition, PS exposure in the outer membrane leaflet of the RBCs membrane is of importance for the adhesion of RBCs to the endothelium in certain diseases such as sickle cell disease, malaria, and diabetes (e.g. [19-23]). Based on a correlation between decreased haematocrit and longer bleeding times [24] and experiments carried out by Andrews and Low [25], an active role of RBCs in thrombus formation has been proposed [25]. A detailed signalling cascade was published by Kaestner et al. [15].

Another possibility for the enhancement of the intracellular $\mathrm{Ca}^{2+}$ content is the activation of protein kinase $\mathrm{C} \alpha(\mathrm{PKC} \alpha)$, e.g. by phorbol-12 myristate-13 acetate (PMA) leading to two independent $\mathrm{Ca}^{2+}$ entry processes. The first is $\mathrm{P}-\mathrm{Type} \mathrm{Ca}_{\mathrm{v}} 2.1$ channel independent and the second is associated with a likely indirect activation of $\mathrm{Ca}_{\mathrm{v}} 2.1$ [26]. PMA is a powerful pharmacological tool that activates PKC $\alpha$ in terms of translocation from the cytosol to the plasma membrane even in the absence of $\mathrm{Ca}^{2+}$ [27].

In all cases of LPA and PMA stimulation the increased intracellular $\mathrm{Ca}^{2+}$ content leads to an externalisation of PS. However, there was no clear correlation between the increased intracellular $\mathrm{Ca}^{2+}$ content and the PS exposure. Most cells with enhanced $\mathrm{Ca}^{2+}$ concentration clearly showed PS exposure. Interestingly, some cells could be found showing an increased intracellular $\mathrm{Ca}^{2+}$ content but no PS exposure, and, vice-versa, some cells that showed PS exposure but no enhanced $\mathrm{Ca}^{2+}$ content $[28,29]$.

To solve the mentioned discrepancies as well as to understand why not all RBCs after stimulation do not react equally with an increased intracellular $\mathrm{Ca}^{2+}$ content as wells as PS exposure, we performed short-time incubation experiments, comparable to the experiments carried out by Nguyen et al. [28], with RBCs separated in 5 fractions with different cell age according to the method of Lutz et al. [2], which was also used for the experiments reported by Ghashghaeinia et al. [13]. The intracellular $\mathrm{Ca}^{2+}$ content and PS exposure at the outer membrane leaflet of human RBCs has been investigated using ionophore A23187 (as positive control), LPA, and PMA. 


\section{Cellular Physiology Cell Physiol Biochem 2016;38:1376-1390

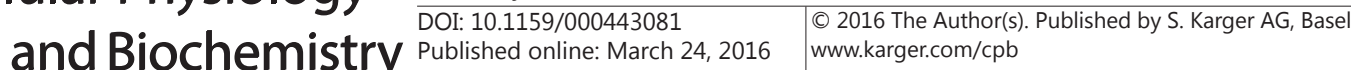 \\ Wesseling et al.: Phosphatidylserine Exposure Depending on Cell Age}

\section{Materials and Methods}

\section{Blood and solution}

Human venous blood from healthy donors was obtained from the Institute of Sports and Preventive Medicine of Saarland University and the Institute of Clinical Haematology and Transfusion Medicine of Saarland University Hospital. EDTA or heparin was used as anticoagulants. Freshly drawn blood samples were stored at $4{ }^{\circ} \mathrm{C}$ and used within one day. Blood was centrifuged at 2,000 g for $5 \mathrm{~min}$ at room temperature and the plasma and buffy coat was removed by aspiration. Subsequently, RBCs were washed 3 times in HEPES-buffered physiological solution (HPS) containing (mM): $\mathrm{NaCl} 145, \mathrm{KCl} 7.5$, glucose 10, HEPES 10, pH 7.4 under the same conditions. After that the RBCs were separated by cell age in 5 different fractions using discontinuous Percoll density gradients according to the method described by Lutz et al. [2]. Finally, the 5 different RBC fractions were re-suspended in HPS and stored at $4{ }^{\circ} \mathrm{C}$ until the beginning of the experiment. The experiment was started immediately after resuspension of the 5 RBC fractions with random order of measurements of the fractions. The experiment of the last fraction was started not later than $3 \mathrm{~h}$ after the beginning of the experiment.

\section{Single labelling experiments}

Measurement of intracellular $\mathrm{Ca}^{2+}$ content: For fluorescent microscopy imaging single labelling experiments were carried out. Measurement of intracellular $\mathrm{Ca}^{2+}$ content: RBCs were loaded with $1 \mu \mathrm{M}$ fluo-4 AM from a $1 \mathrm{mM}$ stock solution in dimethyl sulfoxide (DMSO) in $1 \mathrm{ml}$ HPS. The extracellular $\mathrm{Ca}^{2+}$ concentration was $2 \mathrm{mM}$, i.e. $\mathrm{CaCl}_{2}$ was added to the HPS. Cells were incubated at a haematocrit of $0.1 \%$ in the dark for $30 \mathrm{~min}$ at $37^{\circ} \mathrm{C}$ with continuous shaking. Then the cells were washed again $(16,000 \mathrm{~g}$ for $10 \mathrm{~s})$, with an ice-cold HPS, re-suspended and measured as a control (at room temperature), or incubated with a substance to activate $\mathrm{Ca}^{2+}$ uptake (A23187 $(2 \mu \mathrm{M})$ as positive control, LPA $(2.5 \mu \mathrm{M})$, PMA $\left.(6 \mu \mathrm{M})\right)$ at $37^{\circ} \mathrm{C}$. Stock solutions for A23187 (1 mM), LPA (1 mM), and PMA (10 mM) were prepared in DMSO. The incubation time with one of the three substances was $30 \mathrm{~min}$. After incubation the cells were washed again $(16,000 \mathrm{~g}$ for $10 \mathrm{~s}$ ) with an ice-cold HPS, re-suspended and measured at room temperature.

Measurement of PS exposure: The cells were prepared like for measurement of the $\mathrm{Ca}^{2+}$ content. To detect the PS exposure, annexin V-FITC at a concentration of $4.5 \mu \mathrm{M}$ was used. Annexin binds to PS in the outer layer of the membrane and is coupled with a fluorescent dye (FITC), which can be measured by flow cytometry and fluorescence microscopy [30]. First a control measurement was performed. After that the substances to activate the $\mathrm{Ca}^{2+}$ uptake (A23187, LPA, PMA) were added. The cells were then incubated at 37 ${ }^{\circ} \mathrm{C}$ for $30 \mathrm{~min}$. Then the cells were washed again (16,000 g for $10 \mathrm{~s}$ ) with an ice-cold HPS and re-suspended. Finally, annexin V-FITC was added to the cells. The staining was performed at a haematocrit of $0.1 \%$ in HPS solution with the addition of $2 \mathrm{mM} \mathrm{Ca}^{2+}$ at room temperature for $10 \mathrm{~min}$. The measurements were also performed at room temperature.

The procedure to prepare the RBCs for measurement of intracellular $\mathrm{Ca}^{2+}$ content as well as PS exposure is based on the protocol of Nguyen et al. [28]. The time intervals between various incubation steps were kept as short as possible.

\section{Double labelling experiments}

Although double labelling experiments are common in flow cytometry measurements, there are only few publications where such procedure is used for the investigation of $\mathrm{Ca}^{2+}$ content and PS exposure in RBCs. We followed the protocol developed by Nguyen et al. [28].

For double labelling experiments the same procedure was used as for single labelling experiments to measure the $\mathrm{Ca}^{2+}$ content, i.e. for $\mathrm{Ca}^{2+}$ loading the extracellular $\mathrm{Ca}^{2+}$ concentration was $2 \mathrm{mM}$. However, with double labelling experiments we performed kinetic investigations incubating the cells with the substances (A23187, LPA, PMA) for 1, 5, 10, 15, 20, and $30 \mathrm{~min}$. After the last re-suspension of the RBCs for Ca ${ }^{2+}$ measurements (see above) annexin alexa $647(4.5 \mu \mathrm{M})$ was added (to detect PS) and the cells incubated at room temperature for $10 \mathrm{~min}$.

Fluorescence microscopy

The RBCs were monitored using an inverted fluorescence microscope (Eclipse TE2000-E, Nikon, Tokyo, Japan) as described by Nguyen et al. [28]. The diluted RBC samples (approximately $0.025 \%$ haematocrit) 


\section{Cellular Physiology Cell Physiol Biochem 2016;38:1376-1390 \begin{tabular}{l|l} 
DOI: 10.1159/000443081 & and Biochemistry \\
Published online: March 24, 2016 & $\begin{array}{l}\text { O 2016 The Author(s). Published by S. Karger AG, Basel } \\
\text { www.karger.com/cpb }\end{array}$
\end{tabular} \\ Wesseling et al.: Phosphatidylserine Exposure Depending on Cell Age}

were placed on a cover slip in a dark room at room temperature. Images were taken with an electron multiplication CCD camera (CCD97, Photometrics, Tucson, USA) using a 100x1.4 (NA) oil immersion lens with infinity corrected optics. From each RBC sample, 5 images from different positions of the cover slip randomly chosen were taken using the imaging software Metavue (Universal Imaging Corp., Marlow, UK). Each image consists of one transmitted light and one fluorescence (exposure time $1 \mathrm{~s}$ ) shot. Fluo-4 and annexin V-FITC were excited with a xenon lamp-based monochromator (Visitron Systems, Puchheim, Germany) at a centre wavelength of $488 \mathrm{~nm}$. Emission was recorded at 520/15 nm.

Flow cytometry

Intracellular free $\mathrm{Ca}^{2+}$ content as well as PS exposure was measured by flow cytometry (FACS Calibur and Cell Quest Pro software, Becton Dickinson Biosciences, Franklin Lakes, USA) as described by Nguyen et al. [28] as well as Kucherenko and Bernhardt [31]. $\mathrm{Ca}^{2+}$ was measured in the FL-1 channel (excitation at $488 \mathrm{~nm}$, emission at 520/15 nm). PS exposure in case of annexin V-FITC (single labelling experiments) was detected also in the FL-1 channel. In both cases the positive gates were identified based on control experiments (without stimulating substances). In the control experiments, the maximum amount of cells in the positive gates was less than 1\%. In case of double labelling experiments, PS exposure was determined using annexin alexa 647 with a xenon diode in the FL-4 channel (excitation at $633 \mathrm{~nm}$, emission at 661/8 $\mathrm{nm}$ ). Compensation was not necessary since there was no overlapping. The relative fluorescence intensity was analysed using the mean value of 30,000 cells from each blood sample. To compare the sizes of the RBCs of the different fractions (cp. preparation of RBCs of different cell age, see above) the forward scatter (FSC) signal of the flow cytometer was analysed. For each experiment at least three different blood samples were used.

Determination of the relative cell volume

The relative volume of the RBCs of the different fractions was determined using the dry weight method. RBCs from the same fractions obtained from 4 separation experiments using Percoll density gradient (see above) were pooled in a $1.5 \mathrm{ml}$ Eppendorf tube. The haematocrit was adjusted to $10 \%$ by adding HPS. The samples were centrifuged at $20.000 \mathrm{~g}$ for $7 \mathrm{~min}$ at $4{ }^{\circ} \mathrm{C}$. Then the Eppendorf tube was cut to get the part of the tube, which contains the RBC sediment only. The weight of this part was determined (wet weight) and subsequently this part was dried at $90^{\circ} \mathrm{C}$ for $48 \mathrm{~h}$ (i.e. until constant weight was attained [32]). It was weighted again and the dry weight obtained. The relative cell volume can be easily calculated by: Relative volume (in arbitrary units) = (wet weight - dry weight) / dry weight.

\section{Redox activity measurement}

It is assumed that the plasma membrane redox system (PMRS) activity is changing with cell age [33]. To measure the activity of the PMRS in RBCs of different cell age (fractions 1 - 5), the ferrocyanide assay developed by Avron and Shavit [34] was used. Washed RBCs were re-suspended in ferrocyanide solution (obtained from Roth, Karlsruhe, Germany) at a haematocrit of about $1 \%$ and incubated at $37{ }^{\circ} \mathrm{C}$ for 30 min. The cell suspension was then centrifuged and $0.9 \mathrm{ml}$ of the supernatant was transferred in a reaction solution $\left(0.3 \mathrm{ml}\right.$ sodium acetate, $0.3 \mathrm{ml}$ citric acid, $0.15 \mathrm{ml} \mathrm{FeCl}_{3}, 0.15 \mathrm{ml}$ 4,7-diphenyl-1,1-0-phenandrolin sulfonate solution). The probe was again incubated $\left(23^{\circ} \mathrm{C}, 10 \mathrm{~min}\right.$ ) in the dark. It was analysed at $535 \mathrm{~nm}$ using a photometer (UV mini 1240, Shimadzu, Japan). The obtained optical density was multiplied with factor 0.145 giving the ferrocyanide content of the probe (in $\mu \mathrm{M}$ ) [34].

\section{Reticulocyte determination}

For reticulocyte determination $5 \mu \mathrm{l}$ of RBCs from one of the 5 fractions were re-suspended and incubated in $1 \mathrm{ml}$ retic-COUNT reagent (obtained from BD Biosciences, Heidelberg, Germany) at room temperature in the dark for $30 \mathrm{~min}$. The cells were counted using a flow cytometer (see above) [35].

\section{Determination of protein band 4.1a:4.1b ratio}

The determination of protein band 4.1a:4.1b ratio has been performed according to the method of Mueller et al. [36]. This included the isolation of membrane proteins, determination of protein concentration as well as protein separation by gel electrophoresis. Finally, the gel was scanned in an image file and the band 4.1a:4.1b ratio was determined using the programme ImageJ (internet open source). To demonstrate that 


\section{Cellular Physiology Cell Physiol Biochem 2016;38:1376-1390

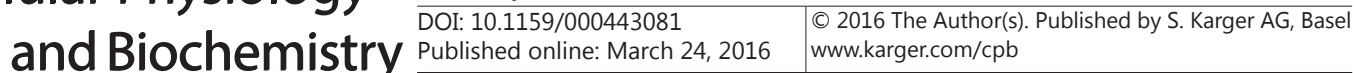 \\ Wesseling et al.: Phosphatidylserine Exposure Depending on Cell Age}

the analyzed protein is identical in size with the band 4.1, a Western blot was done. For Western blotting, the gel was blotted on a PVDF membrane $(70 \mathrm{~V}, 2 \mathrm{~h})$. The membrane was then washed twice with phosphate buffered saline (PBS) and blocked in blocking solution (milk powder $1 \mathrm{~g}, 100 \mathrm{ml}$ PBS with $0.1 \%$ Tween 20) on a shaker over night at $4{ }^{\circ} \mathrm{C}$. The incubation with antibodies followed: Primary antibody (erythroid membrane protein 4.1 (elliptocytosis 1, RH-linked (EPB41)), rabbit anti-human polyclonal antibody (1 $\mu \mathrm{g} /$ ml) (Catalog ID / Lot ID: LS-C80526 / 16044), epitope: N-terminus, commercially available from LifeSpan BioSciences Inc. (Seattle, USA), incubation at room temperature for $60 \mathrm{~min}$. After washing 3 times in PBS with Tween $(0.1 \%$ ) (room temperature, $5 \mathrm{~min}$ ) the incubation with the secondary antibody (goat antirabbit IgG, horseradish peroxidase conjugate (Catalog ID 65-6120)), obtained from Invitrogen (Carlsbad, USA) (diluted $1: 16,000$ ) followed in analogy to the primary antibody. Finally, the membrane was treated with the ECL advanced Western blotting detection kit (from Amersham, UK).

\section{Reagents}

If not mentioned, all chemicals used were purchased from Sigma-Aldrich (Munich, Germany). Fluo-4 AM and annexin V-FITC were obtained from Molecular Probes (Eugene, USA) and annexin alexa 647 from Roche Diagnostics GmbH (Mannheim, Germany).

Statistical significance

Data are presented as mean values \pm SD of at least 3 independent experiments. The significance of differences was tested by ANOVA. Statistical significance of the data was defined as follows: $p>0.05$ (n.s.); $0.01<\mathrm{p} \leq 0.05\left(^{*}\right) ; 0.001<\mathrm{p} \leq 0.01\left(^{* *}\right) ; \mathrm{p} \leq 0.001\left(^{* * *}\right)$.

\section{Results}

One picture of a typical Percoll density gradient with RBCs separated in 5 fractions is presented in Fig. 1. To test the quality of the RBC separation by age, forward scatter (FSC) measurements of cells from fractions 1, 3, and 5 and for comparison of RBCs from whole blood have been carried out. In Fig. 2 one can see that RBCs in fraction 1 (young RBCs) are the biggest in size and that cells are becoming smaller with increasing age. In addition, RBCs from whole blood samples are comparable in size compared with cells of fraction 3 (middle aged RBCs). The statistical analysis is given in the figure legend. These data prove that the RBC separation was efficient. The control data, i.e. FSC of cells without activation, are shown at time zero. Directly after the addition of LPA, i.e. after $1 \mathrm{~min}$, there is a slight but not significant reduction of cell sizes in all samples. The same tendency has been obtained after addition of other activators (A23187 and PMA, data not shown). Analysing the data of the fractions depending on time, only a significant difference of the value at time zero and at time $30 \mathrm{~min}$ for fraction 3 has been found.

In addition to the FCS measurements, the relative cell volume of the different fractions and of non-separated cells was obtained based on the determination of the RBC dry weight (see Methods, $n=4$, in arbitrary units): non-separated cells $=1.83$ \pm 0.16 , fraction $1=2.03 \pm 0.13$, fraction $2=1.87 \pm 0.13$, fraction $3=1.73 \pm 0.10$, fraction $4=1.59 \pm 0.13$, fraction $5=1.50 \pm$ 0.12 . Statistical analysis (ANOVA) revealed that the value of the non-separated cells is significantly different from the values of fraction $5(p \leq 0.05)$. The value of fraction 1

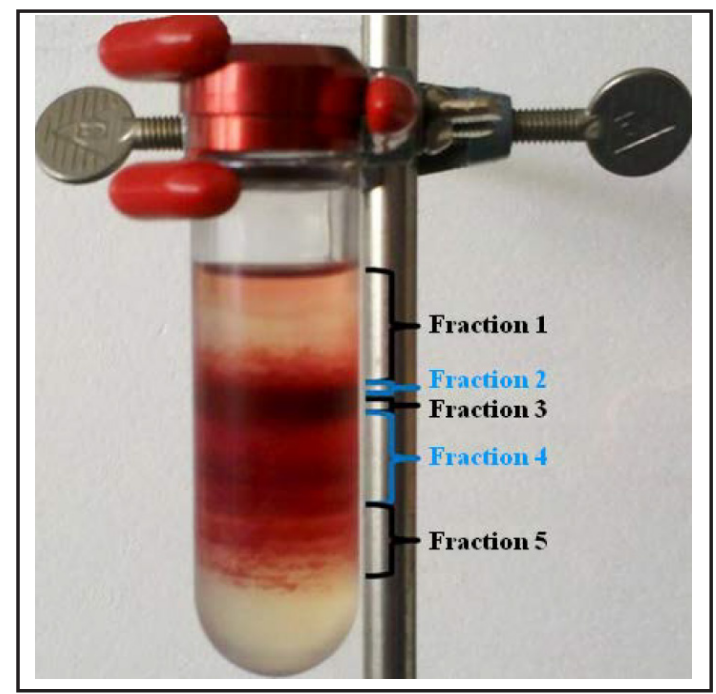

Fig. 1. The picture shows a typical Percoll density gradient with RBCs separated by age in 5 fractions. 
Fig. 2. Forward scatter (FSC) measurements of RBCs from different fractions (cells separated by age) after activation with LPA $(2.5 \mu \mathrm{M})$ using flow cytometry depending on time. White square $=$ non-separated RBCs; dark circle $=$ young cells (fraction 1); dark square = middle aged cells (fraction 3); dark triangle $=$ old cells (fraction 5). $N=3$ (90,000 cells), error bars $=$ S.D. (only half error bar is shown for convenience). Significant differences for fractions at a certain time, ANOVA $\left(0.01<\mathrm{p} \leq 0.05\left(^{*}\right) ; 0.001<\mathrm{p} \leq\right.$ $\left.0.01\left({ }^{* *}\right) ; \mathrm{p} \leq 0.001(* * *)\right)$; for $0 \mathrm{~min}$ : * non-separated (n-s) vs. fraction (fr) 5 , fr 3 vs. fr 5 , ** fr 1 vs. fr 5 ; for

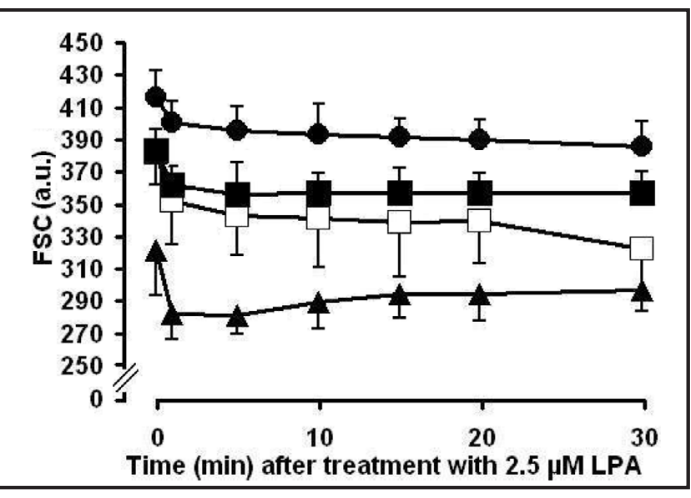
1 min: ${ }^{*} n$-s vs. fr $1,{ }^{* *} n$-s vs. fr 5 , fr 3 vs. fr 5 , *** fr 1 vs. fr 5 ; for 5 min: * $n$-s vs. fr $1, n$-s vs. fr 5 , ** fr 3 vs. fr $5,{ }^{* * *}$ fr 1 vs. fr 5 ; for 10 and 15 min: ${ }^{*}$ fr 3 vs. fr 5 , $^{* *}$ fr 1 vs. fr 5 ; for 20 min: ** fr 1 vs. fr 5 ; for 30 min: * $n$-s vs. fr 1 , fr 3 vs. fr 5 , ** fr 1 vs. fr 5 . Significant differences of separate fractions depending on time: * only for fr 3: 0 min vs. 30 min (only differences between 0 min and $1 \mathrm{~min}$ vs. 30 min have been tested).

Fig. 3. Redox activity (ferrocyanide content) of RBCs from different fractions (cells separated by age) based on flow cytometry measurements. Error bars = S.D.. $N=5(150,000$ cells $)$. Significant differences, ANOVA $\left(0.01<\mathrm{p} \leq 0.05\left(^{*}\right) ; 0.001<\mathrm{p} \leq 0.01\right.$ (*) $^{*}$; $\leq 0.001\left(^{* * *}\right)$ ): *fraction (fr) 2 vs. fr 4 , fr 3 vs. fr $5,{ }^{* *}$ non-separated (n-s) vs. fr 4 , fr 1 vs. fr 3 , fr 2 vs. fr 5 , *** n-s vs. fr 5 , fr 1 vs. fr 4 , fr 1 vs. fr 5 .

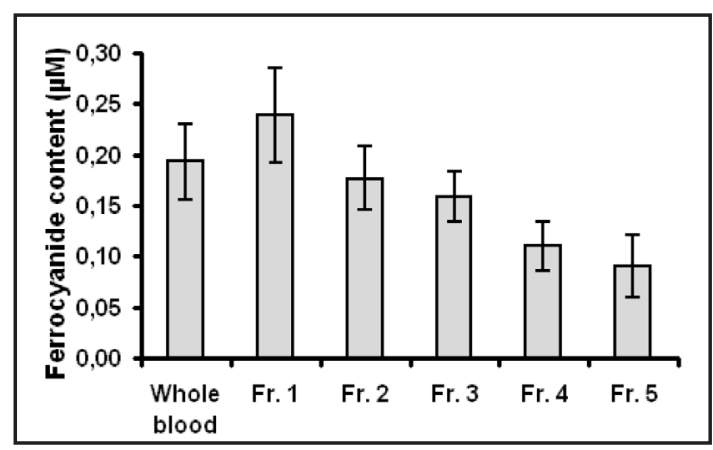

Fig. 4. (A) The picture shows the fragment of the Coomassiestained gel containing the protein band 4.1a and $b$ from RBCs of different fractions (cells separated by age) and non-separated (n-s) cells. (B) Corresponding Western blot showing the protein band 4.1 .

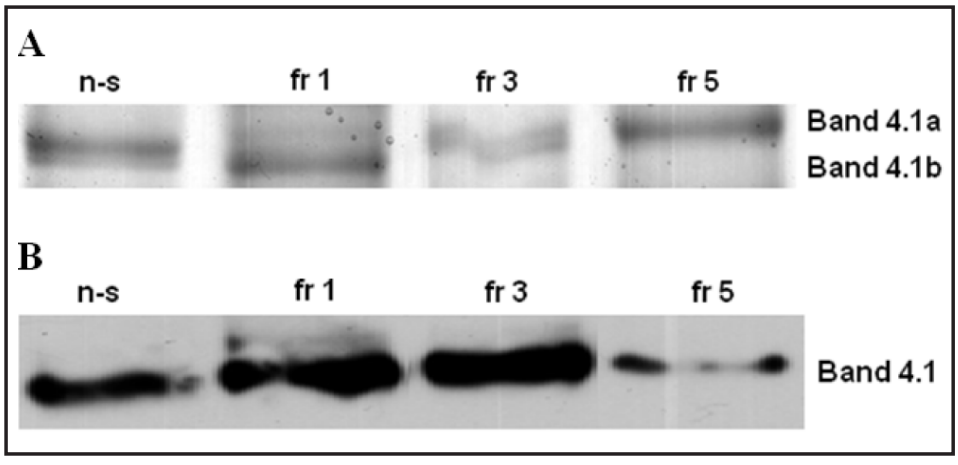

is different from the value of fraction $3(\mathrm{p} \leq 0.05)$, and the value of fraction 1 is different from the value of fraction $5(\mathrm{p} \leq 0.001)$.

Another test was the determination of the amount of reticulocytes in the different fractions. The obtained results showed that reticulocytes are present in fraction 1 to a high amount (11.07 $\pm 6.38 \%$ ). For fraction $2,3,4$, and 5 , the corresponding values are $1.12 \pm$ $0.47 \%, 0.72 \pm 0.58 \%, 0.53 \pm 0.33 \%$, and $0.62 \pm 0.45 \%$, respectively. The value for the nonseparated cells was $0.68 \pm 0.30 \%,(n=4)$. Statistical analysis (ANOVA) revealed that only the value of fraction 1 is significantly different from the values of all other fraction $(p \leq 0.001)$.

Furthermore, the redox activity of the RBCs of the different fractions has been measured and compared with data obtained for cells from whole blood. It can be clearly seen in Fig. 3 that the amount of ferrocyanide, i.e. the activity of the PMRS, is decreasing with increasing age of the RBCs.

Finally, the protein band 4.1a:4.1b ratio has been determined. Fig. $4 \mathrm{~A}$ shows the Coomassie-stained gel containing the protein band $4.1 \mathrm{a}$ and $\mathrm{b}$. An increasing value in the 


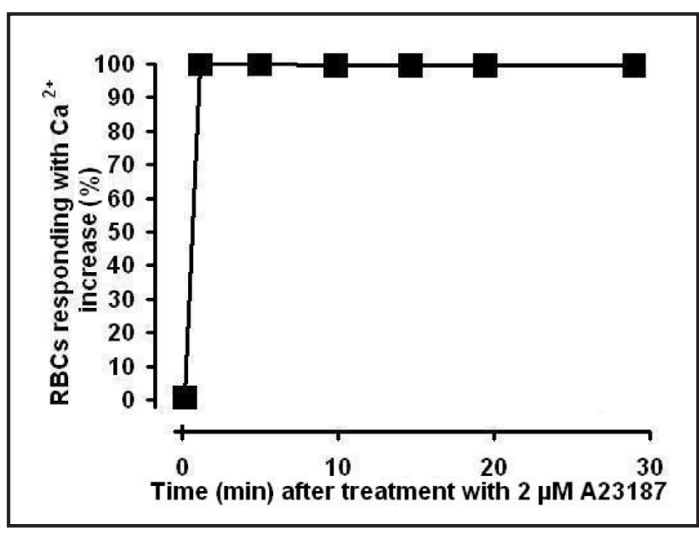

Fig. 5. Percentage of RBCs responding with increased intracellular $\mathrm{Ca}^{2+}$ content from different fractions (cells separated by age) after activation with A23187 $(2 \mu \mathrm{M})$ using flow cytometry depending on time. Non-separated RBCs, young cells (fraction 1); middle aged cells (fraction 3); old cells (fraction 5) have been investigated. There were no significant differences between different fractions. Almost all RBCs of the fractions 1, 3, and 5 show increased intracellular $\mathrm{Ca}^{2+}$ content. That is why a discrimination of the different fractions is not possible (all data fit to the same symbol at different time points). $\mathrm{N}=$ $3(90,000$ cells), error bars $=$ S.D. are smaller than symbols. There are no significant differences between the fractions, ANOVA, $p>0.05$.

Fig. 7. Percentage of RBCs responding with increased intracellular $\mathrm{Ca}^{2+}$ content from different fractions (cells separated by age) after activation with PMA $(6 \mu \mathrm{M})$ using flow cytometry depending on time. White square = non-separated RBCs; dark circle = young cells (fraction 1 ); dark square = middle aged cells (fraction 3); dark triangle = old cells (fraction 5). $\mathrm{N}=3(90,000$ cells), error bars = S.D. (only half error bar is shown for convenience). Significant differences, ANOVA $(0.01<\mathrm{p} \leq 0.05(*))$ for $1 \mathrm{~min}$ : * fraction (fr) 1 vs. fr 3 , fr 1 vs. fr 5 . Significant differences of separate fractions depending on time: ANOVA $\left(0.01<\mathrm{p} \leq 0.05\left(^{*}\right)\right)$ only for fraction $1: 1 \mathrm{~min}$ vs. $30 \mathrm{~min}, 5 \mathrm{~min}$ vs. $30 \mathrm{~min}$ (only differences between $1 \mathrm{~min}$ and $5 \mathrm{~min}$ vs. $30 \mathrm{~min}$ have been tested).

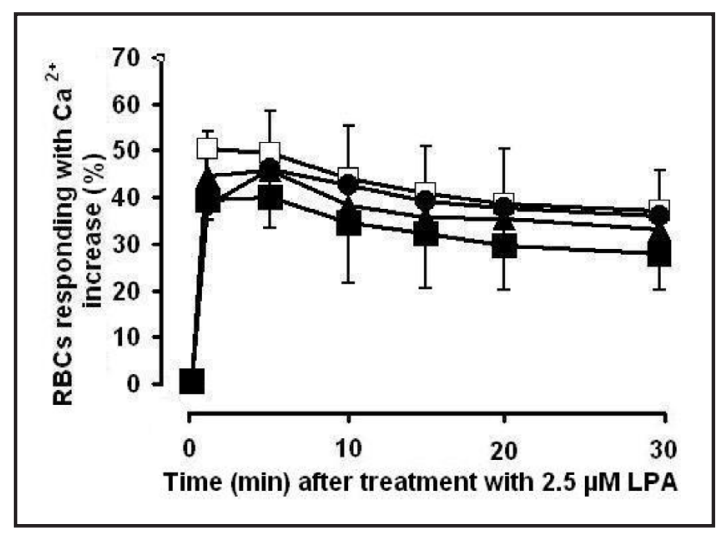

Fig. 6. Percentage of RBCs responding with increased intracellular $\mathrm{Ca}^{2+}$ content from different fractions (cells separated by age) after activation with LPA $(2.5 \mu \mathrm{M})$ using flow cytometry depending on time. White square = non-separated RBCs; dark circle = young cells (fraction 1 ); dark square = middle aged cells (fraction 3); dark triangle = old cells (fraction 5). $\mathrm{N}=3$ (90,000 cells), error bars = S.D. (only half error bar is shown for convenience). There are no significant differences between the fractions, ANOVA, $p>0.05$. Significant differences of separate fractions depending on time: ANOVA $(0.01<\mathrm{p} \leq 0.05$ $(*)$ ) only for fraction 1: 5 min vs. 30 min (only differences between $1 \mathrm{~min}$ and $5 \mathrm{~min}$ vs. $30 \mathrm{~min}$ have been tested).

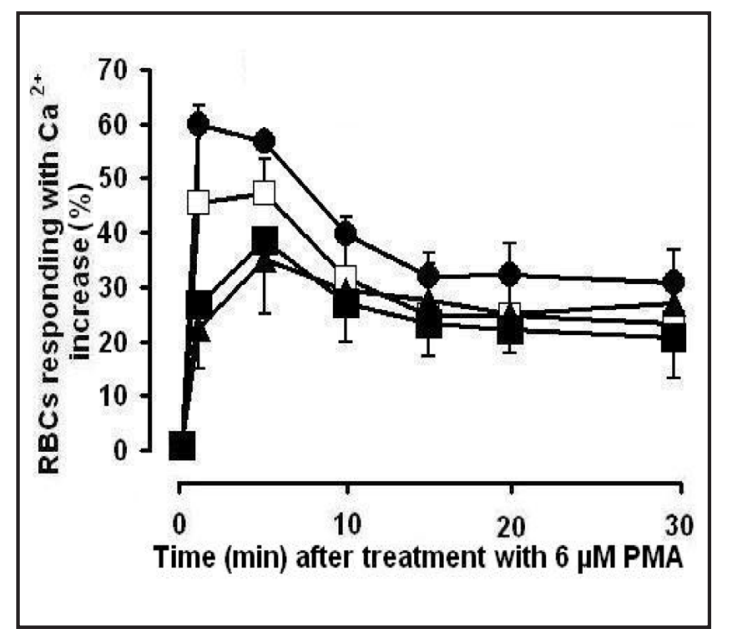

band 4.1a:4.1b ratio with increasing cell age has been determined. The values obtained are $0.179,0.722$, and $>3$ for RBCs from fraction 1,3 and 5 , respectively. The Western blot showing the protein band 4.1 is displayed in Fig. 4B.

When the RBCs were stimulated with the $\mathrm{Ca}^{2+}$ ionophore A23187 (positive control) almost all cells show an increased intracellular $\mathrm{Ca}^{2+}$ content independent on the fraction (Fig. 5). By activation of the RBCs with LPA about $50 \%$ of the cells react with an increased intracellular $\mathrm{Ca}^{2+}$ content (Fig. 6). The maximum of reacting RBCs is reached after 1 - 5 min incubation with LPA. After that a slight decrease can be seen (statistically significant only 


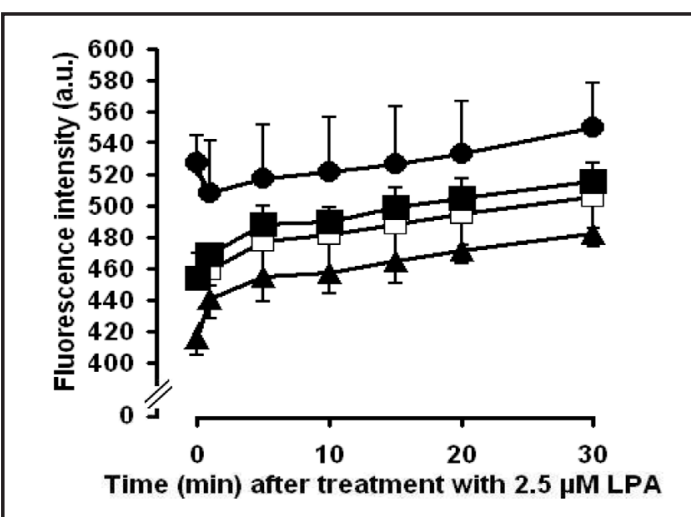

Fig. 8. Fluo-4 fluorescence intensity (arbitrary units) of RBCs from different fractions (cells separated by age) after activation with LPA $(2.5 \mu \mathrm{M})$ using flow cytometry depending on time. White square = non-separated RBCs; dark circle = young cells (fraction 1); dark square = middle aged cells (fraction 3 ); dark triangle $=$ old cells (fraction 5). $\mathrm{N}=3(90,000$ cells), error bars = S.D. (only half error bar is shown for convenience). Significant differences, ANOVA $\left(0.01<\mathrm{p} \leq 0.05\left(^{*}\right) ; 0.001<\mathrm{p} \leq 0.01\left(^{* *}\right)\right.$; for $0 \mathrm{~min}$ : non-separated (n-s) vs. fraction (fr) 1 , fr 1 vs. fr 3 , ** fr 1 vs. fr 5; for $1 \mathrm{~min}, 5 \mathrm{~min}, 10 \mathrm{~min}, 15 \mathrm{~min}, 20 \mathrm{~min}$, 30 min: * fr 1 vs. fr 5. Significant differences of separate fractions depending on time: * for n-s: 0 min vs. $30 \mathrm{~min}, 1 \mathrm{~min}$ vs. $30 \mathrm{~min}$, ** for fr 3 and fr 5: 0 min vs. $30 \mathrm{~min}, 1 \mathrm{~min}$ vs. $30 \mathrm{~min}$ (only differences between 0 min and 1 min vs. 30 min have been tested).

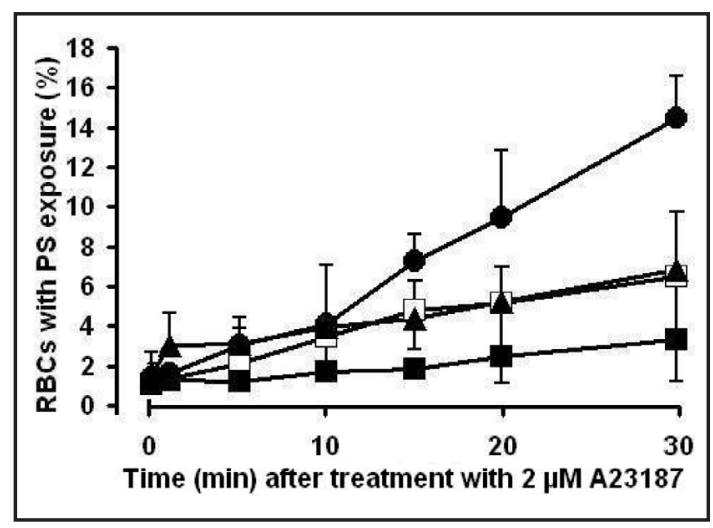

Fig. 9. Percentage of RBCs from different fractions (cells separated by age) showing increased PS exposure after activation with A23187 $(2 \mu \mathrm{M})$ using flow cytometry depending on time. White square = non-separated RBCs; dark circle = young cells (fraction 1); dark square = middle aged cells (fraction 3); dark triangle = old cells (fraction 5). $\mathrm{N}=3$ $(90,000$ cells), error bars $=$ S.D. (only half error bar is shown for convenience). Significant differences, ANOVA $\left(0.01<\mathrm{p} \leq 0.05\left(^{*}\right) ; 0.001<\mathrm{p} \leq 0.01\left(^{* *}\right)\right)$ for $30 \mathrm{~min}$ : * non-separated vs. fraction (fr) 1, fr 1 vs. fr $5,{ }^{* *}$ fr 1 vs. fr 3 .

for the fraction of the young RBCs (fraction 1)). However, there are no significant cell age dependent differences. Using PMA as activator, the same tendency for the increase of the intracellular $\mathrm{Ca}^{2+}$ content as in case of LPA stimulation occurred (Fig. 7). Only 1 min after addition of PMA RBCs of fraction 1 responded significantly more than cells from fractions 3 and 5. After PMA treatment of more than 1 min no significant cell age dependent differences could be detected.

The fluo-4 fluorescence intensity for RBCs from different fractions after treatment with LPA depending on time is shown in Fig. 8. Comparable results were obtained for A23187 and PMA stimulation (not shown). The statistical analysis is given in the figure legend. For nonseparated cells as well as for cells from fraction 1, 3, and 5 there is a slight increase of the fluorescence intensity with time (statistically significant for values of non-separated cells and cells from fraction 3 and 5 at 0 min or 1 min tested versus $30 \mathrm{~min}$ ). In addition, there are significant differences between fraction 1 and 5 over all time points and non-separated versus fraction 1 and fraction 1 versus fraction 3 at $\mathrm{t}=0$ min (Fig. 8).

Investigating the PS exposure after activation with A23187, LPA, or PMA (Figs. 9 - 11) one can see that in all 3 cases there is an increase of the amount of RBCs showing PS at the outer membrane surface with time. However, the amount of cells showing PS exposure after 30 min is different in all three cases, smallest with A23187 and highest with PMA activation. For all 3 activating substances no significant differences between cells from fractions 1, 3, and 5 as well as whole blood could be seen for most time points. Only in case of A23187 stimulation the youngest RBC population (fraction 1) showed a significantly higher amount of cells with PS exposure compared to the other fractions as well as to the non-separated cells after $30 \mathrm{~min}$. 


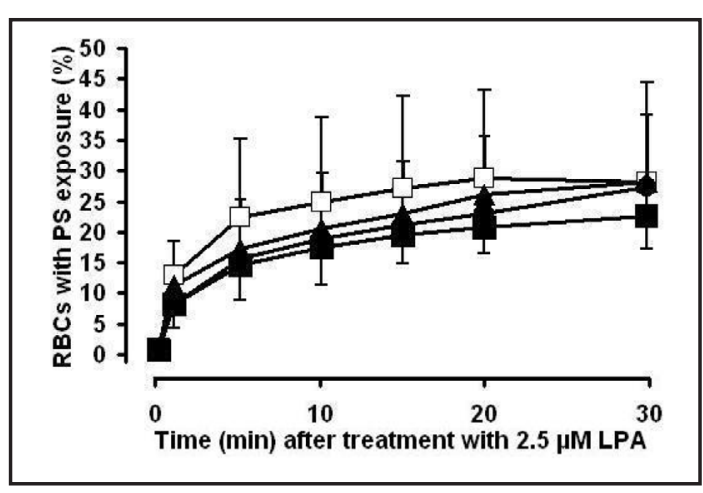

Fig. 10. Percentage of RBCs from different fractions (cells separated by age) showing increased PS exposure after activation with LPA $(2.5 \mu \mathrm{M})$ using flow cytometry depending on time. White square = nonseparated RBCs; dark circle = young cells (fraction 1); dark square = middle aged cells (fraction 3); dark triangle $=$ old cells (fraction 5$) . \mathrm{N}=3$ (90,000 cells), error bars = S.D. (only half error bar is shown for convenience). There are no significant differences between the fractions, ANOVA, $p>0.05$.

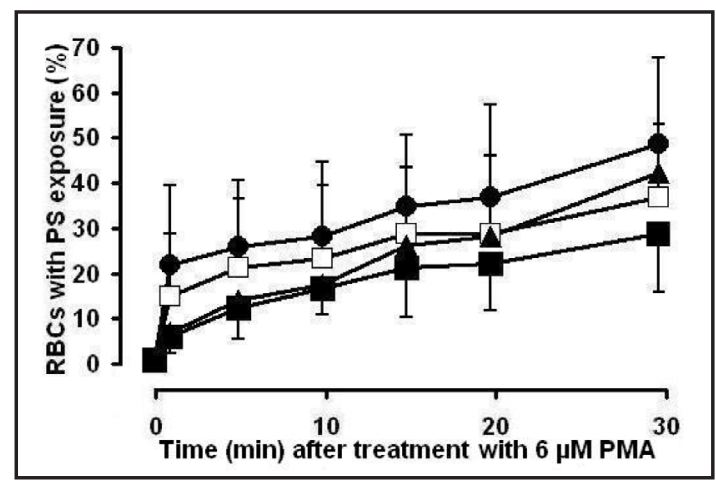

Fig. 11. Percentage of RBCs from different fractions (cells separated by age) showing increased PS exposure after activation with PMA $(6 \mu \mathrm{M})$ using flow cytometry depending on time. White square = nonseparated RBCs; dark circle = young cells (fraction 1); dark square = middle aged cells (fraction 3); dark triangle $=$ old cells (fraction 5$) . \mathrm{N}=3$ (90,000 cells), error bars = S.D. (only half error bar is shown for convenience). There were no significant differences between the fractions, ANOVA, $\mathrm{p}>0.05$.

Table 1. Percentage of RBCs from non-separated, fraction 1, 3, and 5 showing increased intracellular $\mathrm{Ca}^{2+}$ content as well as PS exposure at time zero, i.e. before stimulation with A23187, LPA or PMA (flow cytometry measurements). Data taken from Figs. 6, 10. Mean value \pm S.D., $N=3$ (90,000 cells). There are no significant differences between the fractions, ANOVA, $\mathrm{p}>0.05$

\begin{tabular}{lllll}
\hline & Non-separated RBCs & Fraction 1 & Fraction 3 & Fraction 5 \\
\hline RBCs with increased $\mathrm{Ca}^{2+}(\%)$ & $0.80 \pm 0.09$ & $0.74 \pm 0.20$ & $0.90 \pm 0.53$ & $1.31 \pm 0.69$ \\
RBCs showing PS exposure (\%) & $0.98 \pm 0.15$ & $0.77 \pm 0.07$ & $0.95 \pm 0.31$ & $1.52 \pm 0.37$ \\
\hline
\end{tabular}

It can be seen for control measurements at time zero that there is a slight but not significant increase of the percentage of RBCs showing increased intracellular $\mathrm{Ca}^{2+}$ content as well as PS exposure with increasing age (Figs. 6,10). The obtained values for intracellular $\mathrm{Ca}^{2+}$ content of RBCs from whole blood, fraction 1,3 , and 5 as well as the corresponding PS exposure is presented in Table 1.

In addition to flow cytometry investigations, images of the RBCs of different fractions after activation with A23187, LPA, or PMA were taken using a fluorescence microscope. In this case single labelling experiments for the detection of the increased intracellular $\mathrm{Ca}^{2+}$ content as well as the PS exposure have been performed. Fig. 12 shows the corresponding images for the LPA activation. No remarkable differences can be seen. This was also the case for A23187 and PMA stimulation (not shown).

Furthermore, from the obtained flow cytometry data the percentage of RBCs with an increased PS exposure but no increased intracellular $\mathrm{Ca}^{2+}$ level as well as with an increased intracellular $\mathrm{Ca}^{2+}$ content but no PS exposure after 30 min activation with A23187, LPA, and PMA has been determined. The results are presented in Table 2. No significant age-specific differences could be seen (data not shown).

\section{Discussion}

As one can see from various parameters of RBCs from different fractions (cell size, relative cell volume. reticulocyte content, redox activity, and protein band $4.1 \mathrm{a}: 4.1 \mathrm{~b}$ ratio) 


\section{Cellular Physiology Cell Physiol Biochem 2016;38:1376-1390 \begin{tabular}{l|l} 
and Biochemistry Published online: March 24, 2016 & $\begin{array}{l}\text { (c) 2016 The Author(s). Published by S. Karger AG, Basel } \\
\text { www.karger.com/cpb }\end{array}$
\end{tabular} \\ Wesseling et al.: Phosphatidylserine Exposure Depending on Cell Age}

Table 2. Percentage of RBCs with an increased PS exposure but no increased intracellular $\mathrm{Ca}^{2+}$ level as well as with an increased intracellular $\mathrm{Ca}^{2+}$ content but no PS exposure after 30 min activation with A23187 $(2 \mu \mathrm{M})$, LPA $(2.5 \mu \mathrm{M})$, and PMA $(6 \mu \mathrm{M})$ (flow cytometry measurements). $\mathrm{N}=3(90,000$ cells)

\begin{tabular}{lcc}
\hline Activator & $\begin{array}{c}\text { RBCs with PS exposure, } \\
\text { but no increased Ca } \mathrm{Ca}^{2+} \text { content (\%) }\end{array}$ & $\begin{array}{c}\text { RBCs with increased } \mathrm{Ca}^{2+} \text { content, } \\
\text { but no PS exposure (\%) }\end{array}$ \\
\hline A23187 & $1-2$ & $85-98$ \\
LPA & $3-5$ & $6-12$ \\
PMA & $7-16$ & $2-3$ \\
\hline
\end{tabular}

Fig. 12. Measurements of RBCs from different fractions (cells separated by age) showing transmitted light (A) and corresponding fluorescence image of $\mathrm{RBC}$ with increased intracellular $\mathrm{Ca}^{2+}$ content (B) as well as transmitted light (C) and corresponding fluorescence image of RBCs with increased PS exposure (D) after $30 \mathrm{~min}$ activation with LPA $(2.5 \mu \mathrm{M})$ using fluorescence microscopy (representative images). No significant differences of cells from different fractions could be observed. The figure shows one typical experiment out of 3 .

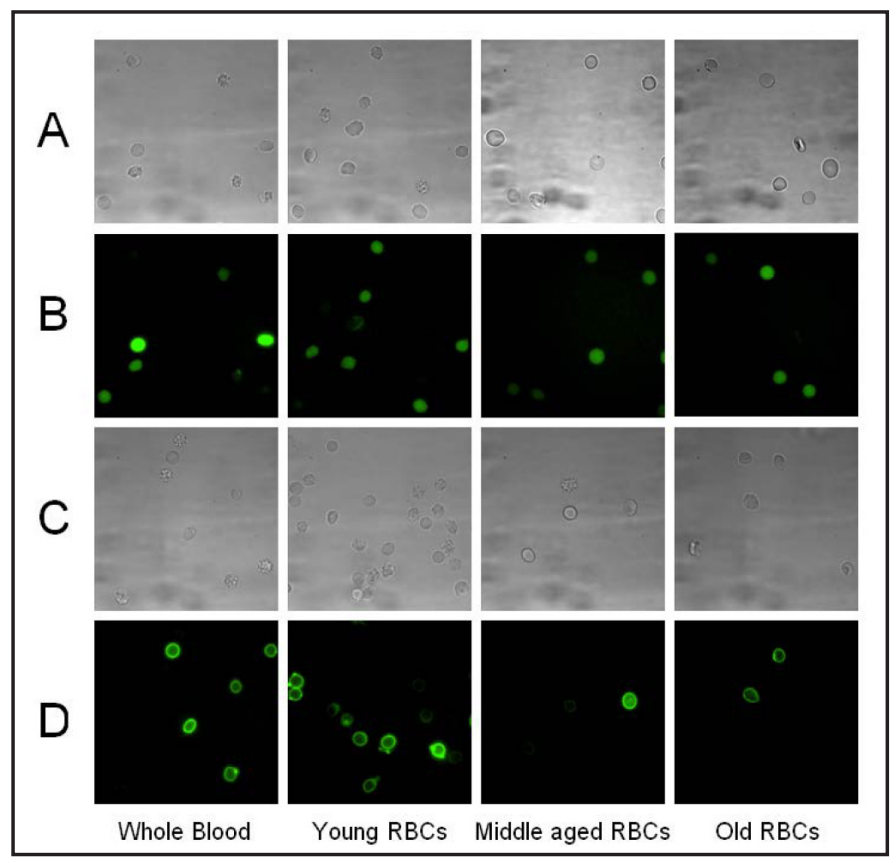

the separation of RBCs by age was successful. The obtained results for these parameters are in agreement with literature data.

RBCs lose water with age and become denser, i.e. smaller (Fig. 2, and data of the relative cell volume) [1,37]. Only shortly before eryptosis, sudden increase in cell volume can be observed [7]. However, the small amount of very old cells in the first fraction (containing the young cells) is negligible. The slight but not significant reduction of the FSC after 1 min is probably based on a shape change of the RBCs. In microscopy experiments we observed that there was a shape change from some discocytes to echinocytes directly after LPA activation (not shown).

Reticulocytes are the youngest RBCs in the bloodstream. They contain residues of RNA. Thiazole Orange (retic-COUNT) binds to RNA and can be analysed by flow cytometry [35]. The analysis of the reticulocyte count in the individual fractions revealed that the reticulocytes were almost exclusively in fraction 1 . Our data also show that the contamination of the other fractions with reticulocytes does not play a substantial role.

The obtained data of the redox activity of RBCs of different age are in agreement with findings of Lawen et al. [33]. When the redox system is less active, less ferrocyanide is formed [38]. D'Alessandro et al. [39] showed a decrease of the anti-oxidant defence-related mechanisms when the RBCs becoming older. A higher Tyr-phosphorylation level of band 3 protein of old compared to young RBCs under hypertonic conditions has been described by Ciana et al. [40]. An overview and a discussion of a variety of markers of the redox activity of RBCs are presented in the review article written by Lutz and Bogdanova [41]. 


\section{Cellular Physiology Cell Physiol Biochem 2016;38:1376-1390

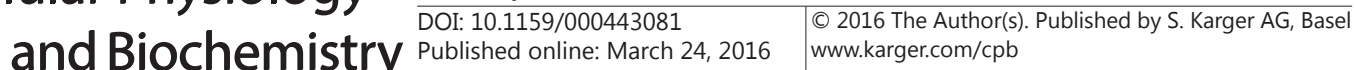 \\ Wesseling et al.: Phosphatidylserine Exposure Depending on Cell Age}

In addition, the observed increase of the protein band $4.1 \mathrm{a}: 4.1 \mathrm{~b}$ ratio with cell age is in agreement with findings reported in the literature [36, 42, 43].

The ionophore A23187 was used as positive control to produce an increase in the intracellular $\mathrm{Ca}^{2+}$ concentration. It is not surprising that almost all RBCs have an increased intracellular $\mathrm{Ca}^{2+}$ content under such conditions. Age-related differences could not be observed. In case of LPA and PMA treatment a maximum amount of RBCs responding with increased intracellular $\mathrm{Ca}^{2+}$ content is reached during the first minutes of stimulation (Figs. $6,7)$. Thereafter, the percentage of RBCs with increased intracellular $\mathrm{Ca}^{2+}$ content is slightly decreasing (significant only for fraction 1). In case of PMA treatment younger RBCs (from fraction 1) respond with a higher amount of cells with increased intracellular $\mathrm{Ca}^{2+}$ content than old or middle-aged RBCs after 1 min of stimulation. It seem realistic to assume that the $\mathrm{Ca}^{2+}$ uptake pathways are less active in old RBCs compared to young ones, which is in agreement with findings of Romero [44] and Makhro et al. [11] showing that young RBCs have a higher $\mathrm{Ca}^{2+}$ uptake capacity than old RBCs. In fact in the paper of Makhro et al. [11] it has been demonstrated that the number of N-methyl-D-aspartate receptor (NMDAR), that contribute to the intracellular $\mathrm{Ca}^{2+}$ regulation, is higher in young cells compared with mature and senescent RBCs. However, it cannot be excluded completely that the old RBCs are less sensitive to PMA and therefore take up less $\mathrm{Ca}^{2+}$. The differences in the decrease of the percentage of RBCs with enhanced intracellular $\mathrm{Ca}^{2+}$ content after the maximum is reached can be explained assuming a higher activity of the $\mathrm{Ca}^{2+}$ pump in young RBCs compared to old and middle-aged RBCs. Such an effect was also reported by Lew et al. [45] and Lucas et al. [46]. The situation is different in experiments with LPA stimulation. In this case there is no significant difference of the increase as well as the declining process between RBCs from different fractions. It should be mentioned that we realised in separate investigations using fluorescence microscopy that in case of LPA or PMA stimulation, some cells take up $\mathrm{Ca}^{2+}$ to such a high amount in a very short time that it leads to the damage of the cells (not shown). Therefore, it seems evident that these cells with high amount of intracellular $\mathrm{Ca}^{2+}$ (probably cells from fraction 1) are damaged already before the flow cytometry measurements started.

In all three cases of stimulation (A23187, LPA, PMA) there is a difference of the fluo-4 fluorescence intensity of the different fractions. For cells from fraction 1 the highest, and for fraction 5 the lowest fluorescence intensity was determined (for LPA see Fig. 8, data for A23187 and PMA are snot shown). Taking into consideration that RBCs from fraction 1 have a higher volume as RBCs from fraction 5 (Fig. 2 and determination of relative cell volume (see Results)), one can assume that the intracellular $\mathrm{Ca}^{2+}$ content of RBCs does not change substantially with cell age. A quantitative statement is not possible since the fluorescence intensity does not change linearly dependent with the $\mathrm{Ca}^{2+}$ concentration [9].

The $\mathrm{Ca}^{2+}$ content of RBCs from whole blood after 30 min activation with A23187, LPA, or PMA was investigated by our group and has been presented in a previous paper [47]. In this publication one can find representative histograms of flow cytometry analysis of intracellular $\mathrm{Ca}^{2+}$ content of RBCs for all 3 substances (Fig. 1 in [47]). In case of stimulation with LPA (Fig. 8) or PMA (not shown) the fluo-4 fluorescence intensity is increasing with time. In contrast, in case of A23187 treatment, the fluorescence intensity does not change significantly with time (measured over $30 \mathrm{~min}$, not shown). This means that a small increase of the intracellular $\mathrm{Ca}^{2+}$ content occurs after LPA or PMA activation taking into consideration a constant or slightly reduced percentage of RBCs with increased intracellular $\mathrm{Ca}^{2+}$ content (Fig. 6).

Whether there is a difference of the intracellular $\mathrm{Ca}^{2+}$ concentration depending on the age of RBCs has been discussed for a long time. It has been described that older RBCs have a higher intracellular $\mathrm{Ca}^{2+}$ content than young RBCs [4, 5, 44]. In contrast, de Haro et al. [10] showed that the $\mathrm{Ca}^{2+}$ level in reticulocytes is higher than in mature RBCs. Assuming a higher intracellular $\mathrm{Ca}^{2+}$ concentration in old RBCs one could assume a higher amount of PS in the outer membrane leaflet of old RBCs compared to young once. On this basis it has been speculated that macrophages recognise old and senescent RBCs with a certain amount of PS in the outer membrane leaflet and remove them from the blood stream [12, 13, 27, 48-52]. 


\section{Cellular Physiology Cell Physiol Biochem 2016;38:1376-1390 and Biochemistry Published online: March 24, $2016 \quad$\begin{tabular}{l|l} 
DOI: 10.1159/000443081 & $\begin{array}{l}\text { (c) } 2016 \text { The Author(s). Published by S. Karger AG, Basel } \\
\text { www.karger.com/cpb }\end{array}$
\end{tabular} \\ Wesseling et al.: Phosphatidylserine Exposure Depending on Cell Age}

Table 3. Percentage of RBCs responding with increased intracellular $\mathrm{Ca}^{2+}$ content and showing increased PS exposure from different fractions (cells separated by age) after $48 \mathrm{~h}$ incubation in Ringer solution containing glucose compared to control ( $0 \mathrm{~h}$ incubation). The experiments were carried out according to the experiments described by Ghashghaeinia et al. [13] (same solutions, only fluo-4 instead of fluo-3 was used). Non-separated RBCs, young cells (fraction 1), middle aged cells (fraction 3), and old cells (fraction 5) have been investigated using flow cytometry. Mean value \pm S.D., $N=3(90,000$ cells). Significant differences for fractions, ANOVA $\left(0.01<\mathrm{p} \leq 0.05\left(^{*}\right) ; 0.001<\mathrm{p} \leq 0.01\left({ }^{* *}\right)\right)$; for $\mathrm{Ca}^{2+}$ content, $48 \mathrm{~h}$ : ${ }^{*}$ fraction (fr) 1 vs. fr 5 , ** non-separated (n-s) vs. fr 5 , fr 3 vs. fr 5 ; for PS exposure, 48 h: * n-s vs. fr 5 , fr 1 vs. fr 5

\begin{tabular}{lcccc}
\hline Fraction & \multicolumn{2}{c}{ RBCs with increased intracellular $\mathrm{Ca}^{2+}$ content $(\%)$} & \multicolumn{3}{c}{ RBCs with PS exposure (\%) } \\
& $0 \mathrm{~h}$ & $48 \mathrm{~h}$ & $0 \mathrm{~h}$ & $48 \mathrm{~h}$ \\
\hline Non-separated & $1.78 \pm 0.83$ & $4.14 \pm 1.11$ & $1.03 \pm 0.17$ & $5.44 \pm 2.63$ \\
Fraction 1 & $3.28 \pm 1.07$ & $5.96 \pm 0.31$ & $1.05 \pm 0.37$ & $4.14 \pm 2.10$ \\
Fraction 3 & $1.91 \pm 1.03$ & $4.13 \pm 1.45$ & $1.31 \pm 0.97$ & $6.56 \pm 1.27$ \\
Fraction 5 & $1.45 \pm 0.20$ & $13.89 \pm 4.79$ & $1.18 \pm 0.80$ & $15.23 \pm 6.03$ \\
\hline
\end{tabular}

Consistent with this idea it was shown that old RBCs responded with a higher increase of intracellular $\mathrm{Ca}^{2+}$ compared to young RBCs, based on flow cytometry measurements using the $\mathrm{Ca}^{2+}$-sensitive dye fluo-3 [13], but interestingly only after a long incubation time of the RBCs (48 h). Such an effect is not surprising if it is taken into consideration that old RBCS have a lower $\mathrm{Ca}^{2+}$ transport rate (e.g. [45]). In addition, the ATP content of older RBCs is decreased faster [53]. We repeated the experiments of Ghashghaeinia et al. [13] carrying out long time incubation ( $48 \mathrm{~h}$ ) of RBCs without activators (same experimental conditions, only fluo-4 instead of fluo-3 for $\mathrm{Ca}^{2+}$ measurements was used) and confirm a significant increase of the intracellular $\mathrm{Ca}^{2+}$ content as well as PS exposure in older cells (Table 3). One could think about a substantial role of ATP for the $\mathrm{Ca}^{2+}$ content and PS exposure in RBCs (see e.g. [54]). However, it has been demonstrated by ATP depletion experiments $(2 \mathrm{~h}$ incubation in the presence of $10 \mathrm{mM}$ inosine, $6 \mathrm{mM}$ iodoacetamide, $5 \mathrm{mM}$ sodium tetrathionate, resulting in an ATP content less than $2 \%$ of its normal level) that little or no ATP is required for the externalisation of PS [29].

Our data at time zero, i.e. before the stimulation (Table 1) show also a slightly higher percentage of older RBCs showing increased intracellular $\mathrm{Ca}^{2+}$ content and PS exposure compared to young ones. However, this effect is not significant and probably also not pronounced enough to explain the clearance of old RBCs from the blood stream on the basis of such mechanism. In the discussion of a possible increased intracellular $\mathrm{Ca}^{2+}$ content in old RBCs it was also proposed that such an increase might occur throughout RBC life in the circulation but this could be transient and rapidly reverted by the $\mathrm{Ca}^{2+}$ pump. Such an explanation was given based on observed increase in the products of $\mathrm{Ca}^{2+}$-dependent proteolysis of phosphotyrosine phosphatases 1B (PTP1B) in old RBCs [40]. For a serious discussion of mechanisms tagging senescent RBCs for clearance in healthy humans we refer to the review article written by Lutz and Bogdanova [41].

The PS exposure is increasing with time in all cases of stimulation (A23187, LPA, PMA) (Figs. 9 - 11). There are no significant differences between the cells from different fractions in case of LPA and PMA stimulation (Figs. 9, 10). Only in case of the positive control (A23187 stimulation) a significant higher value was found for younger RBCs compared to nonseparated, old, or middle-aged RBCs after 30 min stimulation. In case of A23187 stimulation nearly all cells contain a high amount of $\mathrm{Ca}^{2+}$ (see above). However, this effect could be due to a more efficient activation of the PKC and/or the scramblase in young RBCs. It has been described by Franco et al. [12] that older RBCs have a significantly lower aminophospholipid translocase (APLT) activity. However, the amount of cells showing PS exposure is smaller in the case of A23187 stimulation, which is in agreement with earlier findings [28]. It has been already discussed that the $\mathrm{Ca}^{2+}$ increase caused by $\mathrm{A} 23187$ does not lead to an activation of the PKC [28], which plays an important role in the mechanism of PS exposure $\left(\mathrm{Ca}^{2+}\right.$-independent 


\section{Cellular Physiology Cell Physiol Biochem 2016;38:1376-1390 \begin{tabular}{l|l} 
DOI: 10.1159/000443081 & O 2016 The Author(s). Published by S. Karger AG, Basel \\
www.karger.com/cpb
\end{tabular} \\ Wesseling et al.: Phosphatidylserine Exposure Depending on Cell Age}

pathway) $[28,55]$. Carrying out in vivo aging experiments, there was no evidence for elevated PS exposure of older RBCs [12]. It has also been discussed that a shrinkage of RBCs based on an increase of the intracellular $\mathrm{Ca}^{2+}$ content an subsequently activation of the $\mathrm{Ca}^{2+}$-activated $\mathrm{K}^{+}$(Gardos) channel is partly responsible for the PS exposure in RBCs [56]. In this respect it has to be taken into consideration that it was found that the activity of the Gardos channel is reduced with cell aging [57].

Our findings question the idea that the removal of senescent RBCs from the blood stream is simply based on an increased PS exposure in the outer membrane leaflet. However, we are aware of limitations of the presented investigations such as lack of systemic environment, lack of shear stress, etc.

\section{Conclusion}

In summary, we were able to show that there are no significant differences in the intracellular $\mathrm{Ca}^{2+}$ content as well as PS exposure of RBCs of different age after stimulation of $\mathrm{Ca}^{2+}$ uptake and after short-time incubation. In addition, the findings of Nguyen et al. [28] and de Jong et al. [29], showing that some RBCs have an increased intracellular $\mathrm{Ca}^{2+}$ content but no enhanced PS exposure and that some other cells have an elevated PS exposure but no significant increase of the intracellular $\mathrm{Ca}^{2+}$ content cannot be explained assuming that this effect is depending on the age of the RBCs. The reason of the existence of RBCs with such characteristic features is still unclear and will be investigated in future work.

\section{Acknowledgements}

This research is funded by Vietnam National Foundation for Science and Technology Development (NAFOSTED) under grant number 106-YS.06-2013.16 for D. B. Nguyen and a grant from CNPq program "science without borders" to M. C. Wesseling, process number: 202426/2012-2 (Brasil).

\section{Disclosure Statement}

The authors declare no conflict of interest.

\section{References}

1 Piomelli S, Seaman C: Mechanism of red blood cell aging: relationship of cell density and cell age. Am J Hematol 1993;42:46-52.

2 Lutz HU, Stammler P, Fasler S, Ingold M, Fehr J: Density separation of human red blood cells on self-forming Percoll gradients: correlation with cell age. Biochim Biophys Acta 1992;1116:1-10.

3 Risso A, Ciana A, Achilli C, Minetti G: Survival and senescence of human young red cells in vitro. Cell Physiol Biochem 2014;34:1038-1049.

4 Romero PJ, Romero EA, Winkler MD: Ionic calcium content of light dense human red cells separated by Percoll density gradients. Biochim Biophys Acta 1997;1323:23-28.

5 Aiken NR, Satterlee JD, Galey WR: Measurement of intracellular $\mathrm{Ca}^{2+}$ in young and old human erythrocytes using F-NMR spectroscopy. Biochim Biophys Acta 1992;1136:155-160.

6 Woon LA, Holland JW, Kable EP, Roufogalis BD: $\mathrm{Ca}^{2+}$ sensitivity of phospholipid scrambling in human red cell ghosts. Cell Calcium 1999;25:313-20.

7 Lang KS, Lang PA, Bauer C, Duranton C, Wieder T, Huber SM, Lang F: Mechanisms of suicidal erythrocyte death. Cell Physiol Biochem 2005;15:195-202. 


\section{Cellular Physiology Cell Physiol Biochem 2016;38:1376-1390

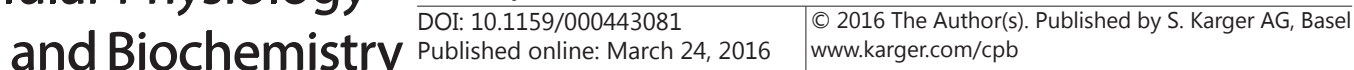 \\ Wesseling et al.: Phosphatidylserine Exposure Depending on Cell Age}

8 Lang F, Gulbins E, Szabo I, Leppel-Wienhues A, Huber SM, Duranton C, Lang KS, Lang PA, Wieder T: Cell volume and the regulation of apoptotic cell death. J Mol Recognit 2004;17:473-480.

9 Kaestner L, Tabellion W, Weiss E, Bernhardt I, Lipp P: Calcium imaging of individual erythrocytes: Problems and approaches. Cell Calcium 2006;39:13-19.

10 de Haro C, de Herreros AG, Ochoa S: Protein phosphorylation and translational control in reticulocytes: Activation of the heme-controlled translational inhibitor by calcium ions and phospholipid. Curr Top Cell Regul 1985;27:63-81.

11 Makhro A, Wang J, Vogel J, Boldyrev AA, Gassmann M, Kaestner L, Bogdanova A: Functional NMDA receptors in rat erythrocytes. Am J Physiol Cell Physiol 2010;299:1571-1573.

12 Franco RS, Puchulu-Campanella ME, Barber LA, Palascak MB, Joiner CH, Low PS, Cohen RM: Changes in the properties of normal human red blood cells during in vivo aging. Am J Hematol 2013;88:44-51.

13 Ghashghaeinia M, Cluitmans JC, Akel A, Dreischer D, Toulany M, Köberle M, Skabytska Y, Saki M, Biedermann T, Duszenko M, Lang F, Wieder T, Bosman GJ: The impact of erythrocyte age on eryptosis. Br J Haematol 2012;157:606-614.

14 Kaestner L, Bollensdorff C, Bernhardt I: Non-selective voltage-activated cation channel in the human red blood cell membrane. Biochim Biophys Acta 1999;1417:9-15.

15 Kaestner L, Tabellion W, Lipp P, Bernhardt I: Prostaglandin E2 activates channel-mediated calcium entry in human erythrocytes: an indicator for a blood clot formation supporting process. Thromb Haemost 2004;92:1269-1272.

16 Oonishi T, Sakashita K, Ishioka N, Suematsu N, Shio H, Uyesaka N: Production of prostaglandins E1 and E2 by adult human red blood cells. Prostaglandins Other Lipid Mediat 1998;56:89-101.

17 Steffen P, Jung A, Nguyen DB, Müller T, Bernhardt I, Kaestner L, Wagner C: Stimulation of human red blood cells leads to $\mathrm{Ca}^{2+}$-mediated intercellular adhesion. Cell Calcium 2011;50:54-61.

18 Kaestner L, Steffen P, Nguyen DB, Wang J, Wagner-Britz L, Jung A, Wagner C, Bernhardt I: Lysophosphatidic acid induced red blood cell aggregation in vitro. Bioelectrochemistry 2012;87:89-95.

19 Closse C, Dachary-Progent J, Boisseau MR: Phosphatidylserine-related adhesion of human erythrocytes to vascular endothelium. Br J Haematol 1999;107:300-302.

20 Tiffert T., Bookchin RM, Lew VL: Calcium homeostasis in normal and abnormal human red cells. In Red cell membrane transport in health and disease; Bernhardt I, Ellory JC. Eds. Springer Verlag: Heidelberg, Germany, 2003; pp.373-405.

21 de Jong K., Larkin SK, Styles LA, Bookchin RM, Kuypers FA: Characterization of the phosphatidylserineexposing subpopulation of sickle cells. Blood 2001;98:860-867.

22 Sherman IW, Prudhomme J, Tait JF: Altered membrane phospholipid asymmetry in plasmodium falciparum-infected erythrocytes. Parasitol. Today 1997;13:242-243.

23 Wali RK, Jaffe S, Kumar D, Kalra VK: Alterations in organization of phospholipids in erythrocytes as factor in adherence to endothelial cells in diabetes mellitus. Diabetes 1988;37:104-111.

24 Hellem AJ: The adhesiveness of human blood platelets in vitro. Scand J Clin Lab Invest 1960;12:1-117.

25 Andrews D, Low PS: Role of red blood cells in thrombosis. Curr Opin Hematol 1999;6:76-82.

26 Wagner-Britz L, Wang J, Kaestner L, Bernhardt I: Protein kinase $\mathrm{C} \alpha$ and P-type $\mathrm{Ca}^{2+}$ channel Cav2.1 in red blood cell calcium signalling. Cell Physiol Biochem 2013;31:883-891.

27 Klarl BA, Lang PA, Kempe DS, Niemoeller OM, Akel A, Sobiesiak M, Eisele K, Podolski M, Huber SM, Wieder T, Lang F: Protein kinase C mediates erythrocyte "programmed cell death" following glucose depletion. Am J Physiol Cell Physiol 2006;290:C244-53.

28 Nguyen DB, Wagner-Britz L, Maia S, Steffen P, Wagner C, Kaestner L, Bernhardt I: Regulation of phosphatidylserine exposure in red blood cells. Cell Physiol Biochem 2011;28:847-856.

29 de Jong K, Rettig MP, Low PS, Kuypers FA: Protein kinase C activation induces phosphatidylserine exposure on red blood cells. Biochemistry 2002;41:12562-12567.

30 Vermes I, Haanen C, Steffens-Nakken H, Reutelingsperger C: A novel assay for apoptosis. Flow cytometric detection of phosphatidylserine expression on early apoptotic cells using fluorescein labelled Annexin V. J Immunol Methods 1995;184:39-51.

31 Kucherenko YV, Bernhardt I: Natural antioxidants improve red blood cell "survival" in non-leukoreduced blood samples. Cell Physiol Biochem 2015;35:2055-2068.

32 Eisenmann AJ, Mackenzie LB, Peters JP: Protein and water of serum and cells of human blood, with a note on the measurement of red blood cell volume. J Biol Chem 1936;116:33-45. 


\section{Cellular Physiology Cell Physiol Biochem 2016;38:1376-1390 \begin{tabular}{l|l|l}
\hline DOI: 10.1159/000443081 & $\begin{array}{l}\text { C } 2016 \text { The Author(s). Published by S. Karger AG, Basel } \\
\text { www.karger.com/cpb }\end{array}$ \\
\hline
\end{tabular}

33 Lawen A, Martinus RD, McMullen GL, Nagley P, Vaillant F, Wolvetang EJ, Linnane AW: The universality of bioenergetic disease: the role of mitochondrial mutation and the putative inter-relationship between mitochondria and plasma membrane NADH oxidoreductase. Mol Aspects Med 1994;15:s13-s27.

34 Avron M, Shavit N: A sensitive and simple method for determination of ferrocyanide. Anal Biochem 1963;6:549-554.

35 Lee L, Chen C, Chiu L: Thiazole Orange: a new dye for reticulocyte analysis. Cytometry 1986;7:508.

36 Mueller TJ, Jackson CW, Dockter ME, Morrison M: Membrane skeletal alterations in vivo mouse red cell aging. Increase in the band 4.1a:4.1b ratio. J Clin Invest 1987;79:492-499.

37 Waugh RE, Narla M, Jackson CW, Mueller TJ, Suzuki T, Dale GL: Rheologic properties of senescent erythrocytes: loss of surface area and volume with red cell age. Blood 1992;79:1351-1358.

38 Rizvi SI, Jha R, Maurya PK: Erythrocyte plasma membrane redox system in human aging. Rejuvenation Res 2006;9:470-474.

39 D’Alessandro A, Blasi B, D’Amici GM, Marrocco C, Zolla L: Red blood cell subpopulations in freshly drawn blood: Application of proteomics and metabolomics to a decades-long biological issue. Blood Transfus 2013;11:75-87.

40 Ciana A, Minetti G, Balduini C: Phosphotyrosine phosphatases acting on band 3 in human erythrocytes of different age: PTP1B processing during cell ageing. Bioelectrochemistry 2004;62:169-173.

41 Lutz HU, Bogdanova A: Mechanisms tagging senescent red blood cells for clearance in healthy humans. Front Physiol 2013;4:article 387.

42 Inaba M, Maede Y: Correlation between protein 4.1a/4.1b ratio and erythrocyte life span. Biochim Biophys Acta 1988;944:256-264.

43 Minetti G, Ciana A, Profumo A, Zappa M, Vercellati C, Zanella A, Arduini A, Brovelli A: Cell age-related monovalent cations content and density changes in stored human erythrocytes. Biochim Biophs Acta 2001;1527:149-155.

44 Romero PJ: Calcium and cell aging: the human red cell as a model. In: Advances in medicine and biology (ed. Bernhardt, LV). Volume 24, pp. 1-133, 2011. Nova Science Publishers, Inc.

45 Lew VL, Daw N, Etzion Z, Tiffert T, Muoma A, Vanagas L, Bookchin RM: Effects of age-dependent membrane transport changes on the homeostasis of senescent human red blood cells. Blood 2007;110:1334-1342.

46 Lucas M, Mata R, Romero A: Comparison of the active calcium extrusion, calcium buffering capacity and ATPase activity in rabbit reticulocytes and mature red cells. Biochim Biophys Acta 1988;942:65-72.

47 Wagner-Britz L, Wang J, Kaestner L, Bernhardt I: Protein kinase $\mathrm{C} \alpha$ and P-type $\mathrm{Ca}^{2+}$ channel $\mathrm{Ca}_{\mathrm{v}} 2.1$ in red blood cell calcium signalling. Cell Physiol Biochem 2013;31:883-891.

48 de Jong K, Emerson RK, Butler J, Bastacky J, Mohandas N, Kuypers FA: Short survival of phosphatidylserineexposing red blood cells in murine sickle cell anemia. Blood 2001;98:1577-1584.

49 Fadok VA, Bratton DL, Rose DM, Pearson A, Ezekewitz RA, Henson PM: A receptor for phosphatidylserinespecific clearance of apoptotic cells. Nature 2000;405:85-90.

50 Verhoeven B, Schlegel RA, Williamson P: Mechanisms of phosphatidylserine exposure, a phagocyte recognition signal, on apoptotic T lymphocytes. J Exp Med 1995;182:1597-1601.

51 Foeller M, Sopjani M, Mahmud H, Lang F: Vanadate-induced suicidal erythrocyte death. Kidney Blood Press Res 2008;31:87-93.

52 Bosman GJ, Were JM, Willekens FL, Novotný VM: Erythrocyte ageing in vivo and in vitro: structural aspects and implications for transfusion. Transfus Med 2008;18:335-347.

53 Vincenzi FF, Hinds TR: Decreased Ca pump ATPase activity associated with increased density in human red blood cells. Blood Cells 1988;14:139-159.

54 Lang F, Gulbins E, Lang PA, Zappulla D, Föller M: Ceramide in suicidal death of erythrocytes. Cell Physiol Biochem 2010;26:21-28.

55 Chung SM, Bae ON, Lim KM, Noh JY, Lee MY, Jung YS, Chung JH: Lysophosphatidic acid induces thrombogenic activity through phosphatidylserine exposure and procoagulant microvesicle generation in human erythrocytes. Arterioscler Thromb Vasc Biol 2007;27:414-421.

56 Maher AD, Kuchel PW: The Gardos channel: A review of the $\mathrm{Ca}^{2+}$-activated $\mathrm{K}^{+}$channel in human erythrocytes. Int J Biochem Cell Biol 2003;35:1182-1197.

57 Tiffert T, Daw N, Etzion Z, Bookchin RM, Lew VL: Age decline in the activity of the $\mathrm{Ca}^{2+}$-sensitive $\mathrm{K}^{+}$channel of human red blood cells. J Gen Physiol 2007;129:429-436. 